\title{
THE FUTURE ORIENTATION FOR NOVICE TEACHER INDUCTION PROGRAM IN VOCATIONAL EDUCATION
}

\author{
Pramudi Utomo \\ Faculty of Engineering, Universitas Negeri Yogyakarta \\ pramudi_ut@uny.ac.id
}

\begin{abstract}
This paper presents the discussion with purpose to identify the orientation of teacher induction program in vocational education that is in line with changing times and future challenges. The problems associated with the teacher induction program in vocational education are whether the program has been oriented towards changes and future challenges. This research was conducted explanatory sequential mixed method approach. This study applies a six-step on research procedure. Respondents consisted of 52 novice teachers, 115 mentors, 15 principals, and 24 school supervisors. The subject of the qualitative research was nine resources persons. The respondents were given a Likert scale questionnaire to gather opinions and to be interviewed about the implementation of induction programs in vocational schools. Data were analyzed using PASW-18 and Atlas.ti software. The results of the study indicate that the future orientation of the induction program for novice vocational teachers involves many aspects in teacher professional development. These aspects include understanding of new target groups, developing job markets, technological developments, business/industry cooperation, regional development, new learning paradigms, and vocational education policy.
\end{abstract}

Keywords: novice, teacher induction, future, vocational education 


\section{INTRODUCTION}

Improving quality and relevance is one of the priorities of education development. Improving quality is being the main purpose according to the rules that it plays in vocational education. Policies and strategies can be used to empower education and training for vocational teachers. Teachers as learning agent having the meaning that the teachers act as a facilitator, motivator, supporter, learning creator, and the learning inspiration for students. Based on these considerations, teacher as learning agents in vocational education need to be mastered include pedagogic competence, professional competence, personality and social competence.

The transformation of teacher education in the twenty-first-century demand for teachers has always been responsive to any changes in it. Teacher challenges in the 21 st century should understand on information literacy and able to develop their knowledge (knowledge building), comprehend media used in the learning process and has a multicultural instinct. Induction program for beginner vocational teacher does not much lead to those understanding. Meanwhile, the core skills of the 21st century and the keys of the student's development characterized by learning and innovation skills, knowledge, information, media and technology, literacy skills, life skills, and citizenship skills (Pacific Policy Research Center. 2010, pp. 7-8). Vocational education needs innovation including skill development and teacher competence, system quality, and learning environment (CERI, 2009, p. 71). The learner society opens insights into learners who can collaborate and share their experiences in order to further integration of 21stcentury skills in the classroom. In the future, vocational education teachers are required to improve productivity by adopting any change to respond global challenges (Marsiti, 2011, p. 166). This needs to be done to increase the quality of education.

Induction program for novice teacher in Indonesia is based on the regulation of the Minister of National Education the number 27-year 2010. Based on this regulation, the induction program implementation in vocational education environment has not been adequate when associated with the needs and the education future orientation. It is necessary for developing the induction program model which accommodate the importance of vocational education. According to Markovic \& Axmann (2006) that training applied to novice teacher focus on the activity of learning both theoretical and practical in the science field. In addition, teachers need a mastery of methods and the new role, the relevance of the business world and industry, as well as the labour market. Teachers or teacher candidates of vocational schools truly cannot be separaed from the industrialized world. The industrial internship experience is a part of the professional teacher development, even though the experience merely review or directly involved in the process of industry practice (Martawijaya, 2011, p. 108).

Some relevant research related to the need for development programs are delivered in a variety of topic induction by many researchers. Stingu (2013) discuss the needs, the implications and any opportunities to build induction program for a novice teacher. Kemmis \& Green (2013) run a cover conception of vocational teachers. Cooper (2013) examine the extent of the support program of induction and mentoring novice teachers. Steele (2013) is emphasized the provision of a certificate as an alternative for the teacher after the induction program. Meanwhile, Chong (2011) reveal the identity of the professional development of teachers.

Based on the description, the future orientation research on induction program for teacher candidates in vocational education needs to be done to find out the urgency. It is important to be understood that induction program become a critical point in the governance for the voted and sort out viable vocational teacher holds his profession.

The problem statement of this research is whether the research programs of vocational education teacher induction has been oriented on changes and challenges of the future? In order to answer this problem statement, the purpose of the research is directed to identify the orientation of teacher induction program of vocational education that is in line with the change and the challenges of the future, particularly teacher education in the 21 st century. The teachers require to always respond to global change.

The succeed of future orientation program of the induction teacher for vocational 
school will have benefits, whether institutional or interelasional. Further, it can be the basic direction of the vocational teacher professional development program systematically through a comprehensive induction by setting the main steps for a teaching profession. Research results can be used as a consideration for the policy study for decision makers.

\section{RESEARCH METHOD}

This research includes descriptive research using mixed methods strategy. Descriptive research is used to describe the topic or phenomenon. Mixed methods research is conducted with the assumption that the collection of various data types can give a comprehensive understanding of the problems (Creswell, 2014, p. 19). For that, the approach used was an explanatory sequential mixed method. The use of mixed methods is to reveal the problem from many perspectives and be able to contextualize the information (Creswell, Klassen, Clark, \& Smith, 2011, p. 5)

This research was done from December 2015 to August 2016. The implementation of collecting data already completed in nine months, not only data from the survey (quantitative data) and interviews (qualitative data), but also other supporting data. According to the mixed method rules, the first phase implemented is quantitative research. The place of the quantitative research is at a vocational school (SMK) in the special region of Yogyakarta (DIY) which organizes the Engineering and Technology program. The next place of the research is the informants office. There are six places for taking qualitative data, i.e. Dinas Pendidikan Provinsi dan Kota/ Kabupaten DIY, SMK Negeri 2 Yogyakarta, SMK Negeri 2 Magelang, LPMP DIY, Kantor Pembinaan dan Penempatan Kerja (Binapenta) Dinas Tenaga Kerja DIY, and PT Mega Andalan Kalasan (MAK).

The subjects of research or the respondent for quantitative research consists of novice teachers $(\mathrm{GPm})$ in amount 52 people, mentor $(\mathrm{GPb})$ in amount 115 people, principal (KS) in amount 15 people and school supervisors (PS) in amount 24 people. These respondents determined in random sampling refers to the formula Krecjie \& Morgan (Isaac $\&$ Michael, 1984, p. 162). Novice teacher data related information and mentor retrieved from the page (http://datapokok.ditpsmk.net/).

Nine respondents were used to get qualitative data. Each of them is the principal, the novice teacher who has been appointed as a civil servant, mentor, Widyaiswara from LPMP, vocational education division head in DIY, head of Binapenta labour Department in DIY, and corporate Secretary PT MAK in DIY. The selection of interviewees as respondents in the research used purposive random sampling.

\section{Procedure}

This study applies a six-step procedure research of mix method (Ivankova, 2006; Creswell, 2013). The first phase begins with the collection of quantitative data against four groups of respondents using questionnaires, observation and documentation. The results obtained the numerical data. The second phase is the analysis of quantitative data which generates the validity coefficient, reliability, frequency tables and descriptive statistics (mean, median, mode and standard deviation). The third phase is linking the results of quantitative research to qualitative step towards, which are the determination of the informant and the drafting of an interview guide. The fourth phase, the qualitative data collection through interviews (interview) with a semistructured individual in-depth question. The fifth phase, the qualitative data analysis is used to develop a code and themes producing a Pareto curve and categorization. The final phase is the results integration of the quantitative with qualitative research. Result interpretation being the basic explanation and discussion of the implications. The research procedure is described below.

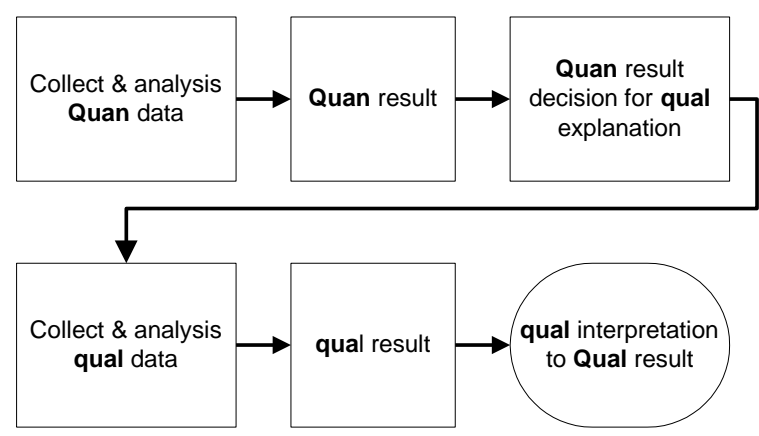

(Adapted from Ivankova, 2006; Creswell, 2013)

Figure 1. Mixed-method Research Procedure 
The research used nominal and audio data. Nominal data came from quantitative research, while the audio data came from qualitative research. Research instrument preparations of quantitative study need considering the structure and determining the focus of observation, as well as data analysis (Scott \& Usher, 2011). The questionnaire is used as an instrument in quantitative research to collect the data. Questions and statements in the questionnaire are composed of sosiodemografi and Likert Scale statement that the content is the future orientation of the teacher induction program. The answers are arranged in four alternative options, i.e. "never/disagree" was given a score of 1; "sometimes/less agree" was given a score of 2; "agree" was given a score 3; and "very often/strongly agree" was given a score of 4 .

Instruments for qualitative research consist of a question list. Questions are developed from the problem and research objectives which not directly criteria, specific, in terms of research, in-depth, and personal (Flick, 2009). In this case, the researchers will serve more as a research instrument. All rules or procedure in asking questions poured in an interview guide.

Data collection technique includes three devices i.e. questionnaires, observation and interview. Observations were conducted to complement the data before the interview. a voice recorder is used to document the results of the interviews with the respondents. In addition, other devices used include telephone, internet, network and interviews guide.

There are two components in the data analysis. First, the descriptive analysis of quantitative data is done to get the values of each variable frequency distribution research. In addition, this analysis is used to know the inclination of the upper central numerical data, including standard deviation. The software is Predictive Analytics SoftWare Statistics version 18 (PASW ${ }^{\circledR}$ Statistics-18). This analysis was chosen considering the instrument which is a questionnaire with four alternative answers.

Second, a descriptive analysis of the qualitative data is used to compile data transcription of the interview until the conclusion. The analysis includes the presentation, coding, condensation, verification and interpretation of results to make a conclusion (Miles,
Huberman, \& Saldana, 2014). Descriptive data analysis used the Atlas. ti. Software.

\section{FINDINGS AND DISCUSSION}

\section{Data Description}

The data described here focused on the respondent's education level. It is a given that education is one of the keys to developing teacher professionalism, including a vocational teacher. The maturity of a thinking way and views also determined by education level. An orientation discussion of the future teacher induction programs need some views and visionary thinking. Based on those reasons, conducting an induction program for novice teachers of vocational education involved many parties, such as mentor, principal, school supervisor, and the Education Office; required to be able to develop the program.

The distribution of the educational level of respondents (Figure 2) shows a fluctuating value. Half of the teacher respondents as much as 26 people got education bachelor degree, then followed by non-educational degree as many as 18 people, seven people got education graduate degree and one person got a non-education graduate degree.

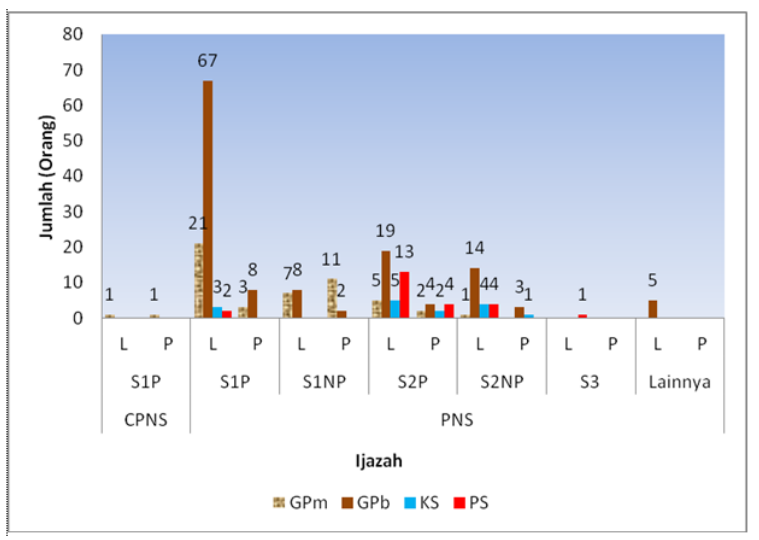

Figure 2. Respondents's Educational Level Distribution

Based on Figure 2, mentor still dominated by education bachelor degree as many as 75 people. This is followed by noneducational bachelor degree as many as 10 people, Master degree as many as 23 people and 17 people non-educational master degree, and five people from undergraduate education level. Principal's education level indicate three people got education bachelor degree, seven people got master of education, and five 
people got a non-educational master degree. Meanwhile, for school supervisor education level, 2 people got education bachelor degree, 17 people got an educational master degree, 4 people got a non-educational master degree, and 1 man got a doctoral degree.

\section{Novice Teacher Induction Program Orientation}

Novice teacher induction program orientation means the orientation of future induction program for novice teachers of vocational education (INTVE). Quantitative data about the orientation of future vocational teacher induction program is obtained by closed questionnaire consisting of 46 statements for novice teachers, 61 statements for mentor, 56 statements each for the principal and School supervisor. Score for each is 1 for a minimum score and 4 for the maximum score, so the total score is $46-184$ for novice teachers, 4-244 for mentor, and each 4-224 for the principal and school supervisor.

The statements for each respondent are arranged with indicators that describe the orientation of future vocational teacher induction programs. The total data collection of a questionnaire for the orientation of future vocational teacher induction programs consists of 12 indicators with descriptions. These are 12 indicators of development-oriented induction program for teacher of vocational education, namely: (1) new target groups, (2) inter-nationalization of teaching materials, (3) regional development, (4) cooperation with the corporate industry, (5) the development of the job fair, (6) vocational education policy/ VET, (7) learning individualization, (8) culture/society change, (9)technological developments, (10) the new learning paradigm, (11) institutional in schools, and (12) educational research.

The orientation of future teachers induction program of vocational education according novice teacher (table 1) can be noted that the indicators of a new target group (average 3.41); the development of job fair (average 3.33); and technological developments (average 3.32); is an important area that needs to be heeded. New target group Indicators can be associated with sub-indicators of student learning needs. Based on those facts, it needs a learning analysis group of students on encouragement, motivation, guidance, and assessment. The cumulative percentage for the third top indicator was recorded by $28 \%$.

Table 1. The Orientation of Future Induction Program Based on the Novice Teacher

\begin{tabular}{clccc}
\hline No. & \multicolumn{1}{c}{ Orientation } & Mean & $\begin{array}{c}\text { Freq. } \\
\text { cum }\end{array}$ & $\begin{array}{c}\text { Cum. } \\
\%\end{array}$ \\
\hline 1 & New Target Group (1) & 3.41 & 3.41 & $10 \%$ \\
2 & Job Fair Development (5) & 3.33 & 6.74 & $19 \%$ \\
3 & Technology Development (9) & 3.32 & 10.05 & $28 \%$ \\
4 & Cultural/Society Changing (8) & 3.28 & 13.33 & $38 \%$ \\
5 & New Learning Paradigm (10) & 3.27 & 16.60 & $47 \%$ \\
6 & Regional Development (3) & 3.26 & 19.86 & $56 \%$ \\
7 & Learning Individualization (7) & 3.24 & 23.10 & $65 \%$ \\
8 & VET Policy (6) & 3.21 & 26.31 & $74 \%$ \\
9 & Education Research (12) & 3.10 & 29.41 & $83 \%$ \\
10 & Institutional/organizational (11) & 3.10 & 32.51 & $92 \%$ \\
11 & Internationalization (2) & 2.93 & 35.43 & $100 \%$ \\
\hline \multicolumn{4}{l}{ Total score } & 35.43 \\
\hline
\end{tabular}

Deepening the labour market opportunity and relevance to the education and training needs to be included in deliberations with the job fair. Other parts of the related technological developments need for adjustment of the material taught in the education and training in accordance with the information technology developments and directions of the industry. In addition, it also needed the understanding of the policies and systems of learning skills in the workplace. Another important indicator according to the orientation of future vocational teacher induction program which needs to be noted is the cultural change with education and training association as well as develop expertise in the collaborative work.

A new learning paradigm which is the idea of the learning development from the business industry for planning the structure of the learning programs, materials, resources and learning media can be a part of the future orientation of the program induction. Regional development indicator needs to strengthen networking between vocational teachers on discussion group or association. One of the Learning individualization Indicators is developing the self-concept of to improve learning. The cumulative percentage of the learning individualization recorded $65 \%$, with the average value equal to and above the average of the total score 3.24 . 
On the other side related to internationalization that means as the integration of international perspectives in the planning of teaching material for novice teachers do not constitute a serious case for the reoriented as a future program induction. No more attention is also shown in the institutional/organizational and educational research problems.

The orientation of future teachers induction program of vocational education according to the mentor (table 2) which can be noted that the indicators of business/industry cooperation (average 3.43); regional development (average 3.41); and technological developments (average 3.40) is an important area that needs to be heeded. Indicators of business/industry networking can be associated with sub-indicators of industry networking. Therefore need communication with the industry to establish a partnership and the opportunity to be shared. For regional development, indicators need to strengthen networking between vocational teacher a plot in the form of deliberation or the association. The cumulative percentage for the third top indicator was recorded in $26 \%$.

Related to the job fair, deepening market opportunity and relevance to the education and training needs to be a concern. Besides that, the technology development needs adjustment of the material taught in the education and training in accordance with the information technology developments and directions of the industry. In addition, the understanding of the policies and systems of learning skills in the workplace. Another important indicator which is the orientation of future vocational teacher induction program is a new learning paradigm that is the idea of the teaching development from the industry for structure planning of the learning programs, materials, resources and learning media in the future orientation of the program induction. Mentor are also giving attention to the future orientation of teacher induction programs of vocational development education policy which one point is to understand the national and international orientation policies of vocational education to associate the education and training program with vocational education policies. In addition, indicators of learning individualization that one of them is developing the self-concept to improve learning and a new target group. The cumulative per- centage indicator to a new target group was recorded of $68 \%$, with a mean value equal to and above the average of the total score 3.30.

Table 2. The Orientation of Future Induction Program According to the Mentor

\begin{tabular}{llrcc}
\hline No. & \multicolumn{1}{c}{ Orientation } & Mean & Freq. & Cum. \\
cum. & $\%$ \\
\hline 1 & Industry Cooperation (4) & 3.43 & 3.43 & $9 \%$ \\
2 & Regional Development (3) & 3.41 & 6.83 & $17 \%$ \\
3 & Technology Development (9) & 3.40 & 10.23 & $26 \%$ \\
4 & Job Fair Development (5) & 3.39 & 13.62 & $34 \%$ \\
5 & New Learning Paradigm (10) & 3.36 & 16.99 & $43 \%$ \\
6 & VET Policy (6) & 3.33 & 20.32 & $51 \%$ \\
7 & Learning Individualization (7) & 3.31 & 23.63 & $60 \%$ \\
8 & New Target Group (1) & 3.31 & 26.94 & $68 \%$ \\
9 & Institutional/organizational (11) & 3.22 & 30.16 & $76 \%$ \\
10 & Education Research (12) & 3.21 & 33.37 & $84 \%$ \\
11 & Cultural/Society Changing (8) & 3.20 & 36.57 & $92 \%$ \\
12 & Internationalization (2) & 3.02 & 39.59 & $100 \%$ \\
\hline \multicolumn{3}{l}{ Total score } & 39.59 & \\
\hline
\end{tabular}

The other part related to inter-nationalization that is meant as the integration of international perspectives in the learning material planning is not an important orientation in the future program induction for mentor. A little attention is also shown in the institutional/organizational research and education as well as a change of culture/society with human resources management principles.

The future orientation of teachers induction program of vocational education according to the principal (Table 3), it can be noted that a new learning paradigm indicators (average 3.60); the cooperation of the industry (average 3.58); regional development (average 3.56); and technological developments (average 3.55) is an important area that needs to be heeded.

A new learning paradigm indicators with sub-indicators could further emphasize on the learning management. Planning the structure of a learning program on the basis of the development of learning theory, instructional development idea came from the industry for planning the structure of the learning programs, materials, resources and media learning. While the industry cooperation can be associated with sub-indicators of networking. Therefore need communication with the industry to establish a partnership and the opportunity to share the work. Regional devel- 
opment indicators need to strengthen networking between a vocational teacher in a group discussion or the association. The cumulative percentage for the third top indicator was recorded in the amount of $26 \%$.

Table 3. The Orientation of Future Induction Program According to the Principal

\begin{tabular}{|c|c|c|c|c|}
\hline No. & Orientation & Mean & $\begin{array}{c}\text { Freq. } \\
\text { cum }\end{array}$ & $\begin{array}{c}\text { Cum. } \\
\%\end{array}$ \\
\hline 1 & New Learning $\mathrm{P}$ & 3.60 & 3.60 & $9 \%$ \\
\hline 2 & Industry Cooperatio & 3.58 & 7.18 & $17 \%$ \\
\hline 3 & Regional Development (3) & 56 & 10.74 & $26 \%$ \\
\hline 4 & Technology I & 55 & 14.29 & $34 \%$ \\
\hline 5 & Learning Indi & 3.52 & 17.81 & $43 \%$ \\
\hline 6 & Institutional/o & 50 & 21.31 & $51 \%$ \\
\hline 7 & Job Fair Development ( & 3.47 & 24.78 & $60 \%$ \\
\hline 8 & New Target Group (1) & 3.42 & 28.20 & $68 \%$ \\
\hline 9 & VET Policy (6) & 3.40 & 31.60 & $76 \%$ \\
\hline 10 & Cultural/Society & 3.40 & 35.00 & $84 \%$ \\
\hline 11 & Education Res & 3.37 & 38.37 & $92 \%$ \\
\hline 12 & Internationalization (2) & 3.13 & 41.50 & $100 \%$ \\
\hline & Total skor & 41.50 & & \\
\hline
\end{tabular}

On the other part of the technology development need for adjustment of the material taught in the education and training in accordance with the information technology developments and directions of the industry. In addition, the individualization of learning indicators develops the value of self-concept to improve learning as well as a new target group.

The principal also looks at institutional/ organizational measures described as the involvement of teachers in institutional networking development and school working management in teamwork that can be oriented in the future induction program for a vocational teacher.

The job fair development is also an important orientation that needs to be deepening market opportunity and relevance to the education and training. In addition also the understanding of the policies and systems of learning skills in the workplace. Cumulative percentage at this job fair development indicators recorded of $60 \%$, with a mean value equal to and above the average of the total score that number 3.47.

Future orientation of vocational education teacher induction program according to School supervisor (Table 4) can be noted that vocational education development policy indicators/VET (average 3.54) is to understand the national policy and international orientation of vocational education to associate the program of education and training policies in the vocational education. With regard to the technology development need for adjusting the material taught in the education and training with the information technology developments and directions of the industry. Regional development indicators need to strengthen networking between a vocational teacher in the form of group discussion or association, and the new paradigm learning (average 3.47) which is an important area that needs to be heeded.

Table 4. The Orientation of Future Induction Program According To School Supervisor

\begin{tabular}{llccc}
\hline No. Orientation & Mean & $\begin{array}{c}\text { Freq. } \\
\text { cum }\end{array}$ & $\begin{array}{c}\text { Cum. } \\
\%\end{array}$ \\
\hline 1 & VET Policy (6) & 3.54 & 3.54 & $9 \%$ \\
2 & Technology Development (9) & 3.53 & 7.07 & $17 \%$ \\
3 & Regional Development (3) & 3.47 & 10.55 & $26 \%$ \\
4 & New Learning Paradigm (10) & 3.47 & 14.02 & $34 \%$ \\
5 & Institutional/organizational (11) & 3.43 & 17.45 & $43 \%$ \\
6 & Industry Cooperation (4) & 3.42 & 20.86 & $51 \%$ \\
7 & Education Research (12) & 3.41 & 24.27 & $59 \%$ \\
8 & Job Fair Development (5) & 3.40 & 27.67 & $68 \%$ \\
9 & Learning Individualization (7) & 3.39 & 31.06 & $76 \%$ \\
10 & New Target Group (1) & 3.33 & 34.39 & $84 \%$ \\
11 & Cultural/Society Changing (8) & 3.33 & 37.72 & $92 \%$ \\
12 & Internationalization (2) & 3.10 & 40.81 & $100 \%$ \\
\hline & Total score & 40.81 & & \\
\hline
\end{tabular}

A new learning paradigm indicators with sub-indicators could further emphasize the learning management. Structure planning of a learning program on the basis of the learning development theory, the idea of the learning development came from the industry for structure planning of the learning programs, materials, resources and media learning. The cumulative percentage for the fourth top indicator was recorded of $34 \%$.

School Supervisor also looked at institutional as described as teacher involvement in the networking development institutions and the schooling work management in the teamwork that can be used as the future orientation of the program vocational teacher induction. While the industry cooperation can 
be associated with industry networking subindicators. Communication need with the industry to establish a partnership and the opportunity to share the work. Educational research elements that provide opportunities and research opportunities in the vocational education and training, need to be filled as a part of the orientation of future vocational teacher induction programs according to school supervisor. Cumulative percentage on this educational research indicators recorded in amount $59 \%$, with a mean value equal to and above the average of the total score that number 3.41. On the other hand, with the integration of internationalization is meant as an international perspective in the planning of learning material, which is not taken as a serious case for the reoriented as a future induction program vocational teacher by the School Supervisor. Learning Individualization which is to develop the value of self-concept to improve learning and development, is also an important orientation. The need for deepening market opportunity and relevance to the work of education and training.

\section{Future Orientation Analysis of the INTVE}

The orientation of future teacher induction program of vocational education from the novice teacher's perspective, supervising teachers, principals, and school supervisor indicates a different emphasis, but there is the same side for the anticipation in the implementation process. The orientation of future vocational teacher induction programs according to novice teachers put more emphasis on the aspects of a new target group that is described as a learning needs analysis followed by encouragement, motivation and direction as well as an assessment against the learning achievements of students. In addition, an emphasis is placed on work development and the technology development. mentor emphasize on the partnership with the industry, regional development and technology development to fill the future orientation of the program of vocational teacher induction. The principal in the orientation of future vocational teacher induction program has a greater emphasis on learning new paradigms, and cooperation with the industry, as well as regional development. Meanwhile, school supervisor emphasizes on vocational education development policy, technology development and the regional development in the orientation of future vocational teacher induction programs. Aspects of technology development become a staple for the pressure groups of respondents, except the principal. Regional development has also become a staple for the pressure groups of respondents, except the novice teacher. The principal and supervisor also stressed the importance of cooperation with the industry.

At a later stage, the orientation of future vocational teacher induction programs that need to get attention for a new paradigm development is individualization of learning and instruction. It does not mean that the other aspect is not important, but the main point is the aspect which is explained above. The problem of internationalization in the learning planning material, four respondent groups showed the same opinion while this is not yet a major concern of future programs of vocational education teacher induction. In addition, there is a culture/society change, educational research, and institutional/organizational as well as a new target group that gets the same emphasis as internationalization aspects.

According to the theory of Prosser \& Quigley (1949, p. 217) associated with vocational education, teachers should be able to convey the lesson that follows the principles of the work environment industry. This understanding is based on the phenomenon that the principle of vocational education will be efficient if the environment in which the learners are trained is an artificial environment where the students will be working. Teachers at vocational education will effectively run the tasks and learn, education and training when it is done in ways, operational tools, and the same tools as used in the industry. According to the induction program theory by Wong (2005), the induction program should be a multi-year comprehensive process of designed to train and adapt to novice teachers in academic standards and vision of the government/local government. Induction programs will be effective if it has three basic principles that be implemented, according to Wong (2005), namely: (1) comprehensive, coherent, (2) and (3) sustainable.

Based on the interviews, respondents pointed out that the learning method development should pay attention to the skills of the 21 st century that demands creativity, critical 
thinking, communication, and collaboration (4 $\mathrm{k})$. One of the widyaiswara of LPMP YOGYAKARTA gives his opinion that the changes and challenges of the era are more associated with teacher induction program for vocational education implementation.

"... the competence of the 21st century, one of which is the aspect of communication means there demands literacy. Literacy IT is very important. So the learning development methods must notice $4 K$ that along with the literacy development. I guess that it supposes to be initial modal to develop a accommodating learning on the dynamics of changes. "

Supervising teacher see that induction programs for new vocational teacher needs to be given to improving their skills and productive skills. Even the mentor asserted if INTVE given for a period of one year is considered still lacking. The reason given is related to the complexity of the development of technologies that must be mastered by the productive teacher.

"Expertise is linked to productive skills. Indeed if in a year for the skills/ competencies I say less. In that year, if it's in a building with complex technological development now once I guess still less".

The principal of SMKN in Yogyakarta City and Magelang City looked at how important employment system must be understood by novice teachers in the teacher induction program. Thus his opinion:

"... a system of employment need to be conveyed in the teacher induction program, this is important because a teacher would become a reformer. However, this teacher provide insight to their students"

The school principal said that it is ideal when there is a prolific teacher ever worked in the industry or at least never follow on the job training (OJT) in the industry.

"... so it's ideal for the productive teacher had worked in the industry, one that. Ideally, a teacher can provide the latest information, he also has the company, one of them with OJT. School preparing teachers with OJT, working in the industry".
When the speaker from PT DIY MAK (industrial) confirmed about the existence of a desire to make OJT as part of teacher induction program agenda of vocational education, it turns out that industry thus provides internship program with some prepared projects.

"It is possible with industry.., could prepare the internship program for teachers later we engage in specific projects so that teachers have industrial experience related to their best practice. Implemented in an industry that later can be transmitted by teachers to the students because the teacher already had specific expertise".

Novice teacher and mentor need to be given the opportunity to explore experience and knowledge in the industry. The actual experience gained for the learning improvement. School supervisor looked at the industry that it is the most suitable place to deepen the material and professional competence.

"... For overall competence analysis, at the school for three years. Competencies which could not be carried out in school will be collected as materials or competencies that are expected of it obtained in the industry".

\section{CONCLUSION}

\section{Summary}

The future orientation of INTVE involves many aspects in the professional teacher formation. Important aspects that need to be included in the INTVE are: (1) understanding the new target groups, (2) job fair development, (3) technological develop-ment, (4) the business/industry networking, (5) regional development, (6) a new learning paradigm, and (7) vocational education policy.

Important aspects in implementing INTVE based on the learning theory development. The aspects related to the structure planning of the learning program, the idea of learning development with input from the business/industry for learning materials, resources and learning media. The cooperation of the business/industry is associated with the network of the work, communication with the industry to establish a partnership and the opportunity to share the work. Regional de- 
velopment indicators strengthened the need for networking between vocational teachers as group discussion or the association.

Novice teacher and mentor mentioned that technological development is an important aspect that needs to be known in the formation of professional teacher. Adjustment of the material taught in the education and training tailored to the information technology develop-ment and the direction of the work, including an understanding of the policies and systems of learning skills at work.

The main point of vocational education development policy is understanding the national policies and international orientation of vocational education to be able to associate the program of education and training policies.

\section{Recommendations}

Communication with the industry need to be constantly maintained to keep the partnership and the opportunity work. Stakeholders need to strengthen networking between vocational teachers in the form of deliberation, association or joint activities to support the regional development. Facilitating a new learning paradigm could be more emphasized on learning management and quality assurance.

Coordination between stakeholders need to be more rigorously because organizing INTVE involve many parties. Each party, as newbie teacher, mentor, principal, school supervisor, and local governments have different roles.

\section{REFERENCES}

CERI. (2009). Innovation in education and vocational education and training. Included in: Working out change systemic innovation in vocational education and training. Paris: OECD Publishing.

Chong, S. (2011). Development of teachers' professional identities: From pre-service to their first year as novice teachers. KEDI Journal of Educational Policy, 8(2), 219-233.

Cooper, B. J. (2013). The impact of a comprehensive induction program to reduce the attrition rate of novice teachers. Walden University. Retrieved from http:// gradworks.umi.com/36/00/3600073.html

Creswell, J. W. (2013). Research design: pendekatan kualitatif, kuantitatif, dan mixed (Terjemahan Achmad Fawaid). Yogyakarta: Pustaka Pelajar

Creswell, J. W., Klassen, A. C., Clark, V. L. P., \& Smith, K. C. (2011). Best practices for mixed methods research in the health sciences. Lincoln: Office of Behavioral and Social Sciences Research

Creswell, J. W. (2014). Research design: qualitative, quantitative, and mixed methods approaches (4th ed.). Thousand Oaks, CA: Sage Publications, Inc.

Flick, U. (2009). An introduction to qualitative research. Los Angeles: Sage Publicati-ons, Inc.

Isaac, S., \& Michael, W. B. (1984). Handbook in research and evaluation (2nd ed.). San Diego, CA: Edits Publishers.

Ivankova, N.V., Creswell, J.W. \& Stick, S.L. (2006). Using mixed-methods sequential explanatory design: From theory to practice. Field Methods, 18(1), 3-20. DOI: $10.1177 / 1525822 X 05282260$. Sage Publications.

Kemmis, R. B., \& Green, A. (2013). Vocational education and training teachers' concept-ions of their pedagogy. International Journal of Training Research, 11(2), 102-121.

Markovic, J., \& Axmann, M. (2006). "Vocational pedagogy" in vocational education teacher training (Vol. Vocational Education and Training Reform Programme). Belgrade: Ministry of Education and Sports Republic of Serbia.

Marsiti, C. I. R. (2011). upaya peningkatan mutu pendidikan sekolah menengah kejuruan melalui pengembanagan profesionalisme guru. Jurnal Pendidikan Vokasi, 1(1), 157-168. Retrived from https://journal.uny.ac.id/index.php/jpv/ar ticle/view/5810

Martawijaya, D. (2011). Pengembangan program pendidikan guru pendidikan teknologi dan kejuruan TransNasional. Jurnal Pendidikan Vokasi, 
1(1), 91-112. Retrieved from https://journal.uny.ac.id/index.php/jpv/ar ticle/view/5802

Miles, Matthew B., A. Michael Huberman, \& Johnny Saldaña. (2014). Qualitative data analysis: A methods sourcebook $\left(3^{\text {rd }}\right.$ edition). Thousand Oaks CA: SAGE Publications, Inc.

Pacific Policy Research Center. (2010). $21^{\text {st }}$ Century Skills for Students and Teachers. Honolulu: Kamehameha Schools, Research \& Evaluation Division.

Prosser, C. A., \& Quigley, T. H. (1949). Vocational education in a democracy. Chicago, IL: American Technical Society.

Scott, David and Robin Usher. (2011). Researching Education: Data, Methods and Theory in Educational Enquiry-2nd ed. London: Continuum International Publishing Group.

Steele, T. E. (2013). An investigation of the perceptions of induction support of first year alternatively certificated teachers (Dissertations, and Capstone Projects. Paper 583.). Kennesaw State University, Kennesaw, GA. Retrieved from http:// digitalcommons.kennesaw.edu/etd/583

Stingu, M. (2013). Induction of newly qualified teachers: Limits, needs and opportunities. The Journal of Education Culture and Society, (1), 148-157.

Wong, H. K. (2005). New teacher induction: The foundation for comprehensive, coherent, and sustained professional development. In Teacher mentoring and induction: The state of the art and beyond, By Hal Portner (pp. 41-58). Thousand Oaks, CA: Corwin Press. 